\title{
Suppression of predatory behaviors in laboratory mice following lithium chloride injections or electric shock
}

\author{
CHARLES S. KLUNDER and MICHAEL O'BOYLE \\ University of Southern Mississippi, Hattiesburg, Mississippi 39401
}

\begin{abstract}
The present study compared the relative effectiveness of electric shock and lithium chloride ( $\mathrm{LiCl}$ ) injections in suppressing cricket killing and eating by mice. Male ICR mice were tested for cricket killing and eating. Mice that attacked and ate a cricket were punished (with electric shock or $\mathrm{LiCl}$ injections) after killing and eating crickets. Control mice received saline injections, delayed shock, or delayed $\mathrm{LiCl}$ injections after attacking and eating crickets. $\mathrm{LiCl}$ injections and electric shock were both effective in suppressing cricket killing and eating. Shock suppressed both attack and eating responses, while $\mathrm{LiCl}$ injections suppressed eating responses more than attack responses.
\end{abstract}

Predatory behaviors have been modified by means of punishment procedures using stimuli that have been used in taste aversion studies (e.g., Gustavson, Kelly, \& Sweeney, 1976), as well as by more conventional punishing stimuli (e.g., electric shock). For example, mousekilling in rats has been suppressed by punishment procedures using electric shock (e.g., Myer \& Baenninger, 1966) or induced illness (Berg \& Baenninger, 1974; Clody \& Vogel, 1973; Krames, Milgram, \& Christie, 1973; O'Boyle, Looney, \& Cohen, 1973). Given the importance of biological constraints on learning and conditioning (e.g., see Seligman \& Hagar, 1974), it would be of interest to compare the relative effectiveness of different punishers upon different predatory behaviors. While there is evidence that induced illness suppresses eating responses more effectively than attack responses (Berg \& Baenninger, 1974; Krames, Milgram, \& Christie, 1973), direct comparisons between different punishers are needed.

The cricket-killing response of mice is a convenient model of predation (Butler, 1973; Lowe \& O'Boyle, 1976; Thomas 1969). The present study examined the relative effectiveness of selected intensities of electric shock and selected dosages of lithium chloride $(\mathrm{LiCl})$ in suppressing the predatory behavior of mice toward crickets.

The levels of aversive stimuli used in the present study were chosen so that the highest levels (i.e., 2-mA electric shock, $2 \%$ body weight of $.15 \mathrm{M} \mathrm{LiCl}, \mathrm{IP}$ ) could

This study is based on a thesis submitted by the first author to the University of Southern Mississippi in partial fulfillment of the MA degree in psychology. This study was supported in part by Grant 1 R03 MH 2636-01 USM from the National Institute of Mental Health. Requests for reprints should be sent to James Lowe, Chairman, Psychology Department, Box 25, Southern Station, Hattiesburg, Mississippi 39401. reasonably be expected to cause some suppression of predatory behavior. Two-percent body weight of $0.15 \mathrm{M}$ $\mathrm{LiCl}$, injected interperitoneally, reliably produces learned taste aversions (e.g., Nachman, 1970). This dosage has also been used to suppress cricket-killing in mice (Lowe \& O'Boyle, 1976). Myer and Baenninger (1966) used 1.5-mA, 3-sec-duration electric shocks to suppress mouse-killing in rats.

\section{METHOD}

\section{Subjects}

Ninety male Dub/ICR (Flow Laboratories) mice, approximately 35 days of age at the start of the study, served as subjects. Domestic crickets (Acheta domesticus), obtained from a local bait shop, served as prey targets. Mice were housed individually in wire mesh cages (Hoeltge Model LC-75/A). Purina Rat Chow and water were available in the home cages throughout the study.

\section{Apparatus}

Mice were tested in a mouse toggle-floor shuttle cage (BRS/ LVE Model 146-02) $27 \times 12 \times 19 \mathrm{~cm}$ high. Scrambled shock could be delivered to the grid floor of the shuttle cage by means of a shock generator (BRS/LVE Model SG-903) and a shock scrambler (BRS/LVE Model SC-902).

\section{Procedure}

Upon arrival in the laboratory, the mice were individually housed and allowed to adapt to their home cages for at least 3 days. Screening and testing procedures began after this period. The 90 mice were tested in three phases. Three separate groups of 32,40 , and 18 mice were studied over three separate 15 day periods. Identical procedures were followed within each phase.

\section{Adaptation}

On Days $1-3$, each mouse underwent daily $15-\mathrm{min}$ adaptation periods alone in the shuttle cage.

\section{Screening and Punishment Trials}

On Day 4, each mouse was exposed to a cricket which was taped to a wall in the shuttle cage. The cricket's hind legs were taped to its body. The cricket was then taped to the wall such 
that its head, antenna, and front four legs were exposed. Of the 147 mice screened, $90(61 \%)$ attacked and ingested part of the cricket within $15 \mathrm{~min}$. These mice served as subjects for the remainder of the study. On Days 4-8, each mouse received daily $15-\mathrm{min}$ trials in the shuttle cage with a cricket. Punishment was administered according to the procedures outlined below. If no attack took place, it was assumed that the behavior was suppressed for that day and no injection or shock was administered.

The 90 subjects were randomly assigned to one of the following punishment or control groups:

Group L.5\% (10 subjects) was injected with $\mathrm{LiCl}$ (.5\% of body weight of $.15 \mathrm{M} \mathrm{LiCl}$, IP) $3 \mathrm{~min}$ after first attacking and eating part of the cricket. An attack response was defined as pouncing, biting, or tearing a cricket with the forepaws (Butler, 1973). Eating was defined as ingesting some part of the cricket. Groups L1\% and L2\% (10 subjects/group) were treated exactly as Group L.5\%, except that the dosage of $\mathrm{LiCl}$ was $1 \%$ and $2 \%$, respectively.

Groups S.5, S1, and S2 (10 subjects/group) were administered a $3-\mathrm{sec}$ electric shock 3 min after first attacking and ingesting part of the cricket. Shock intensity was $.5,1.0$, and $2.0 \mathrm{~mA}$ in the three groups, respectively.

Group C1 (5 subjects) was allowed to attack and ingest part of the cricket for a 3-min period. No punishments were administered. This procedure was used to control for any changes in predatory behavior due to repeated cricket presentations.

Group C2 (5 subjects) was allowed to attack and ingest part of the cricket for a 3-min period, then returned to the home cages. Approximately $3-4 \mathrm{~h}$ later, the subjects were returned to the shuttle cage and administered a $2-\mathrm{mA}$ shock for $3 \mathrm{sec}$. This procedure was used to control for any suppressive effects of shock due to the association of shock with the shuttle cage, as opposed to the cricket.

Group C3 (10 subjects) was injected with $\mathrm{NaCl}$ (2\% of body weight of .15 M NaCl, IP) at the end of a 3-min period after attacking and ingesting part of the initial cricket. This procedure controlled for the effects of the injection itself.

Group C4 (5 subjects) was allowed to attack and ingest part of the cricket for a 3-min period, then returned to the home cages. Approximately $3-4 \mathrm{~h}$ later, the subjects were injected with $\mathrm{LiCl}$ ( $2 \%$ of body weight of $.15 \mathrm{M} \mathrm{LiCl}$, IP). This procedure controlled for any suppressive effects of $\mathrm{LiCl}$ injections due to debilitation.

Group C5 (5 subjects) was allowed to attack and ingest part of the cricket for a 3-min period, and then returned to the home cages. Approximately 3-4 h later, the subjects were injected with $\mathrm{LiCl}$ ( $2 \%$ of body weight of $.15 \mathrm{M} \mathrm{LiCl}$, IP), then returned to the shuttle cage for $15 \mathrm{~min}$. This procedure was used to control for any suppressive effects of $\mathrm{LiCl}$ due to the association of $\mathrm{LiCl}$ injections with the shuttle cage, as opposed to the cricket.

\section{Recovery Trials}

On Days 9-15, 15-min recovery trials were held to determine the course of recovery of the attack and eating responses. Recovery trials consisted of a 15-min exposure to a cricket, with no injections or shock being administered. Trials 9-14 were conducted in the shuttle cage as before. Trial 15 was held in the home cage of each mouse. Attack and ingestion latencies were recorded by one observer. Reliability was checked on approximately $25 \%$ of all trials by having a second observer independently record attack and ingestion latencies.

\section{RESULTS}

The attack and eating latency data are summarized in Table 1. The results indicated that the predatory behavior of mice towards crickets was suppressed by means of punishment procedures using electric shock or toxic $\mathrm{LiCl}$ injections. Shock was the more effective punisher.

The suppression of predatory behaviors was a punishment effect, and not due to injections or electric shock per se, since the predatory responses of the control mice were relatively unaffected by saline injections or noncontingent punishment. The cricket appeared to be the essential cue which mediated the suppression of attack and eating responses. The attack and eating latencies increased for shocked mice, whether they were tested in the shuttle cage or in their home cages. The increase in eating latency generalized to the home cage for the $\mathrm{LiCl}$ group as well. The environmental cues of the shuttle cage or the home cage did not seem to affect attack or eating latencies.

With regard to different levels of punishment, it was

Table 1

Median Attack and Eating Latencies Over Test Conditions

\begin{tabular}{|c|c|c|c|c|c|c|c|c|c|}
\hline \multirow[b]{2}{*}{ Treatment } & \multirow[b]{2}{*}{ Group } & \multicolumn{2}{|c|}{$\begin{array}{c}\text { Initial Punishment } \\
\text { Trial Latency } \\
\end{array}$} & \multicolumn{2}{|c|}{$\begin{array}{r}\text { Punishment Trials } \\
\text { Median Latencies } \\
\end{array}$} & \multicolumn{2}{|c|}{$\begin{array}{c}\text { Recovery Trials } \\
\text { Median Latencies } \\
\end{array}$} & \multicolumn{2}{|c|}{$\begin{array}{l}\text { Home Cage } \\
\text { Trial Latency }\end{array}$} \\
\hline & & Attack & Eat & Attack & Eat & Attack & Eat & Attack & Eat \\
\hline $\mathrm{LiCl}$ & $\begin{array}{l}.5 \% \\
1.0 \% \\
2.0 \% \\
\text { Combined }\end{array}$ & $\begin{array}{l}213.0 \\
248.0 \\
397.0 \\
315.5\end{array}$ & $\begin{array}{l}354.0 \\
351.0 \\
451.0 \\
409.0\end{array}$ & $\begin{array}{l}260.5 \\
167.5 \\
370.5 \\
313.0\end{array}$ & $\begin{array}{l}515.5 \\
345.5 \\
777.0 \\
541.0\end{array}$ & $\begin{array}{l}249.0 \\
265.0 \\
352.0 \\
272.5\end{array}$ & $\begin{array}{l}830.5 \\
667.5 \\
900.0 \\
875.5\end{array}$ & $\begin{array}{l}169.5 \\
218.0 \\
257.5 \\
237.0\end{array}$ & $\begin{array}{l}503.0 \\
658.5 \\
679.0 \\
612.5\end{array}$ \\
\hline Shock & $\begin{array}{l}.5 \mathrm{~mA} \\
1.0 \mathrm{~mA} \\
2.0 \mathrm{~mA} \\
\text { Combined }\end{array}$ & $\begin{array}{l}341.5 \\
205.0 \\
301.0 \\
279.0\end{array}$ & $\begin{array}{l}484.5 \\
294.0 \\
410.0 \\
401.5\end{array}$ & $\begin{array}{l}672.5 \\
678.0 \\
838.5 \\
722.5\end{array}$ & $\begin{array}{l}738.0 \\
787.5 \\
889.0 \\
813.5\end{array}$ & $\begin{array}{l}900.0 \\
900.0 \\
900.0 \\
900.0\end{array}$ & $\begin{array}{l}900.0 \\
900.0 \\
900.0 \\
900.0\end{array}$ & $\begin{array}{l}778.5 \\
816.5 \\
900.0 \\
829.5\end{array}$ & $\begin{array}{l}817.5 \\
823.5 \\
900.0 \\
896.5\end{array}$ \\
\hline Control & $\begin{array}{l}\text { Shock* } \\
\text { Saline } \\
\text { Delayed LiCl } \\
\text { Combined }\end{array}$ & $\begin{array}{l}343.0 \\
360.5 \\
362.5 \\
362.5\end{array}$ & $\begin{array}{l}450.0 \\
406.5 \\
485.0 \\
417.0\end{array}$ & $\begin{array}{l}236.0 \\
294.0 \\
295.0 \\
291.0\end{array}$ & $\begin{array}{l}377.0 \\
369.5 \\
407.0 \\
395.5\end{array}$ & $\begin{array}{l}229.5 \\
208.5 \\
210.5 \\
212.0\end{array}$ & $\begin{array}{l}348.5 \\
286.0 \\
297.0 \\
301.5\end{array}$ & $\begin{array}{l}146.5 \\
207.5 \\
146.0 \\
157.5\end{array}$ & $\begin{array}{l}188.5 \\
291.5 \\
231.0 \\
214.0\end{array}$ \\
\hline
\end{tabular}

*Shock = No-shock and delayed-shock groups (C1 and C2). 
found that increasing the $\mathrm{LiCl}$ dose tended to increase eating, but not attack, latencies. An examination of the different shock level groups did not reveal great differences in predatory latencies. Thus, all levels of shock used here effectively suppressed predatory responses. The lowest shock intensity was too strong to yield any graded effects.

The data analysis leading to these conclusions included analysis of variance and chi-square tests. An analysis of variance revealed no significant differences between Group C1, no shock; Group C2, delayed shock (2 mA); Group C3, saline; Group $\mathrm{C} 4$, delayed $\mathrm{LiCl}$ (home cage); and Group $\mathrm{C} 5$, delayed $\mathrm{LiCl}$ (shuttle cage) $(p>.05)$ with regard to attack or eating latencies across all phases of the experiment. These groups were collapsed to comprise one general control group of 30 mice.

Since the present experiment was designed to compare different punishment modalities, the three sub. groups of each punishment condition were also combined (Groups L.5\%, L1\%, and L2\%; S.5 mA, $\mathrm{S} 1 \mathrm{~mA}$, and S2 $\mathrm{mA}$ were combined). Thus, the nine subgroups were collapsed to form three groups: shock, $\mathrm{LiCl}$, and control groups, with 30 mice in each group.

An analysis of variance comparing the $\mathrm{LiCl}$, shock, and control groups indicated that no significant differences existed between the three groups on the initial punishment trial with regard to attack or eating latency ( $p>.05)$. Thus the predatory responses of the mice prior to punishment were similar. Analyses of variance were not used to assess punishment effects, since the variance of the latency measurements was zero in some cells (shock punishment groups during recovery).

A significant chi square $\left[\chi^{2}(2)=71.34, p<.001\right]$ was achieved with regard to the number of mice that failed to attack the cricket at least once (Table 2). Significant differences existed between the $\mathrm{LiCl}$ and shock groups $\left[\chi^{2}(1)=45.88, p<.001\right]$ and between the shock and control groups $\left[\chi^{2}(1)=56.13, p<.001\right]$, but not between the $\mathrm{LiCl}$ and control groups $(\mathrm{p}>.05)$ No mice in the shock group consistently attacked the cricket, whereas $15 \mathrm{LiCl}$ mice and 28 control mice never failed to attack the cricket.

A comparison of the number of mice failing to eat a cricket at least once resulted in a significant chi square $\left[\chi^{2}(2)=56.27, p<.001\right]$ (Table 3 ). Significant differ-

Table 2

Mice Failing to Attack at Least Once

\begin{tabular}{lccc}
\hline & \multicolumn{3}{c}{ Treatment } \\
\cline { 2 - 4 } & LiCl & Shock & Control \\
\hline Refusers & 15 & 0 & 28 \\
Attackers & 15 & 30 & 2 \\
Total & 30 & 30 & 30 \\
\hline
\end{tabular}

Note-Refusers: number failing to attack at least once; attackers: number never failing to attack.
Table 3

Number of Mice Failing to Eat the Cricket

\begin{tabular}{lrcc}
\hline & \multicolumn{3}{c}{ Treatment } \\
\cline { 2 - 4 } & LiCl & Shock & Control \\
\hline Refusers & 21 & 30 & 2 \\
Eaters & 9 & 0 & 28 \\
Total & 30 & 30 & 30 \\
\hline
\end{tabular}

Note-Refusers: number failing to eat at least once; eaters: number never failing to eat.

ences existed between the $\mathrm{LiCl}$ and shock groups $\left[\chi^{2}(1)\right.$ $=10.59, \mathrm{p}<.01]$, the $\mathrm{LiCl}$ and control groups $\left[\chi^{2}(1)\right.$ $=25.45, \mathrm{p}<.001]$, and the shock and control groups $\left[\chi^{2}(1)=52.5, \mathrm{p}<.001\right]$. Of the nine mice in the LiCl groups never failing to eat, four were in the $.5 \%$ body-weight group and five were in the $1 \%$ body-weight group, indicating that the $2 \%$ dosages tended to suppress eating more than the lesser dosages.

Reliability was checked on approximately $25 \%$ of the trials by having a second observer independently record the attack and/or eating latencies of the mice. Agreement on latencies was high, with differences in recorded latencies never exceeding $10 \mathrm{sec}$. This result is consistent with Butler's (1973) data regarding the high interobserver reliability for measuring the latency of a predatory attack by a mouse upon a cricket.

\section{DISCUSSION}

Our major finding was that while both $\mathrm{LiCl}$ injections and electric shock were effective in suppressing predatory behaviors, shock was a more effective punisher. In the shock groups, significantly more mice failed to attack the cricket than did mice in the $\mathrm{LiCl}$ groups. Shock suppressed both attack and eating behaviors. Mice injected with $\mathrm{LiCl}$ tended to continue attacking the crickets, while showing a marked reduction in eating behavior. The result is consistent with prior work using mouse-killing rats. Berg and Baenninger (1974) found that rats injected with $\mathrm{LiCl}$ after killing and eating mice showed a significant decrease in eating, but no decrement in killing behavior. Krames, Milgram, and Christie (1973) found that immediate $\mathrm{LiCl}$ injections, which produced a suppression of feeding, produced virtually no suppression of attack. It appears that punishers are not equally effective for all classes of stimuli. In the present study, it seems that the noxious consequences of "sickness" were associated with eating cues, while electric shock was associated with attack responses, even though shock was administered $3 \mathrm{~min}$ after eating began.

While the results of the present experiment support prior notions (e.g., Berg \& Baenninger, 1974) that different classes of aversive stimuli may be differentially effective in suppressing predatory behaviors, they should 
be interpreted with caution. First, only a few levels of shock and $\mathrm{LiCl}$ dose were examined. It may be the case that higher levels of $\mathrm{LiCl}$ would suppress attack latencies as well as eating behaviors.

Second, the comparison of different punishers is necessarily complex. Although the present results are consistent with the idea that shock is associated with attack responses, and toxic injections are associated with ingestive responses, there are alternative explanations. The two treatment modalities (shock and $\mathrm{LiCl}$ ) differ in a number of ways, particularly in their temporal relation to the behavior punished. It may be the case that the intrinsic delay imposed between $\mathrm{LiCl}$ injections and the aversive consequences make toxic injections more suitable for punishing ingestive responses. The importance of temporal factors was highlighted by Krane and Wagner (1975), who reported that an acquired aversion to saccharin or to a light and tone could be demonstrated when these stimuli were followed by electric shock, but that the optimal interval for avoidance between stimulus and shock varied with the particular cue. When a light-tone was the stimulus, substantial aversion developed at $5 \mathrm{sec}$, and none at $210 \mathrm{sec}$. When saccharin was the stimulus, substantial aversion developed at $210 \mathrm{sec}$, and none at $5 \mathrm{sec}$. The role of temporal factors in affecting differences between punishment modalities should be investigated in more detail.

\section{REFERENCES}

Berg, D. . \& Baenninger, R. Predation: Separation of aggressive and hunger motivation by conditioned aversion. Journal of
Comparative and Physiological Psychology, 1974, 86, 601-606.

BUtLER, K. Predatory behavior in laboratory mice: Sex and strain comparisons. Journal of Comparative and Physiological Psychology, 1973, 85, 234-249.

Clody, D. E., \& Vogel, J. R. Drug induced conditioned aversion to mouse killing in rats. Pharmacology, Biochemistry. and Behavior, 1973, 1, 477-481.

Gustavson, C., Kelly, D., \& Sweeney, M. Prey-lithium aversions. I: Coyotes and wolves. Behavioral Biology, 1976, 17. 61-72.

Krames, L., Milgram, N., \& Christie, D. Predatory aggression: Differential suppression of killing and feeding. Behavioral Biology, 1973, 9, 641-647.

Krane, R. V., \& WAgner, A. R. Taste aversion learning with a delayed shock US: Implications for the "Generality of the laws of learning. Journal of Comparative and Physiological Psychology, 1975, 88, 882-889.

LOWE, W., \& O'BoYLE, M. Suppression of cricket killing in laboratory mice following lithium chloride injections. Physiology \& Behavior, 1976, 17, 427-430.

Myer, J. S., \& Baenninger, R. Some effects of punishment and stress on mouse killing by rats. Joumal of Comparative and Physiological Psychology, 1966, 62, 292-297.

NACHMAN, N. Learned taste and temperature aversions due to lithium chloride sickness after temporal delays. Journal of Comparative and Physiological Psychology, 1970, 73, 22-30.

O'BOYLE, M., LOONEY, T., \& CoHEN, P. Suppression and recovery of mouse killing in rats following immediate lithium chloride injectiuns. Bulletin of the Psychonomic Society, 1973, 1, 250-252.

Seligman, M. E. B., \& Hager, R. Biological boundaries of learning. New York: Appleton-Century-Crofts, 1974.

Tномаs, K. Predatory behavior in two strains of laboratory mice. Psychonomic Science, 1969, 15, 13-14.
(Received for publication August 29, 1977; revision accepted July 20.1978 .) 